\title{
Compaction and cover effects on runoff and erosion in post-fire salvage logged areas in the Valley wildfire, California
}

\author{
Sergio Prats ${ }^{1}$, Maruxa Malvar ${ }^{2}$, and Joseph Wagenbrenner ${ }^{3}$ \\ ${ }^{1}$ University of Aveiro \\ ${ }^{2}$ Universidade de Aveiro \\ ${ }^{3}$ US Forest Service
}

June 9,2020

\begin{abstract}
Runoff and erosion can increase after wildfires, but little is known about the effects of wildfire plus post-fire salvage logging, or mitigating these effects. Past research has identified soil compaction and reduced surface cover as controls on runoff and erosion, but the relative contributions of these changes are not clear. Two years after high severity burning by the 2015 Valley Fire in California, replicated rainfall simulations were carried out in four soil conditions across compaction and cover factors: uncompacted/compacted by logging machinery and bare soil/60\% wood slash-cover. Runoff after 71 mm of rainfall totaled 27 $\mathrm{mm}$ in the uncompacted bare plots and $39 \mathrm{~mm}$ in the compacted bare plots. Runoff in the slash-covered plots decreased by $50 \%$ and $33 \%$ as compared to the uncompacted and compacted bare plots, respectively, although none of the differences in runoff were significant. Rainsplash averaged $30 \mathrm{~g}$ for the bare plots, regardless of compaction, and decreased significantly by $70 \%$ on slash-covered plots. Sediment yield totaled 460 and $818 \mathrm{~g} \mathrm{~m}-2$ for the uncompacted and compacted bare plots, respectively, and slash significantly reduced these amounts by $72 \%$ and $69 \%$, respectively. Our results showed that post-fire soil erosion in high severity burned unlogged areas was still very high two years after the wildfire. The combination of wildfire and salvage logging doubled soil erosion by increases in both runoff amount and sediment concentration. Antecedent soil moisture (dry or wet) was the dominant factor for runoff, while surface cover was the dominant factor for erosion and sediment delivery. Covering the soil with slash reduced both runoff and erosion, suggesting this treatment would reduce long-term sediment delivery from burned areas and skid trails. Saturated hydraulic conductivity $(\mathrm{Ks})$ and interrill erodibility (Ki) calculated from these simulations confirmed previous research and will support modeling efforts related to wildfire and post-fire salvage logging.
\end{abstract}

Compaction and cover effects on runoff and erosion in post-fire salvage logged areas in the Valley wildfire, California

Slash and compaction effects on post-fire hydrology and erosion.

Prats Sergio Alegre ${ }^{a b^{*}}$, Malvar Maruxa Cortizo ${ }^{\text {ab }}$, Wagenbrenner Joseph William ${ }^{b}$

a Centre for Environmental and Maritime Studies (CESAM), Department of Environment and Planning, University of Aveiro, Campus Universitário de Santiago, 3810-193 Aveiro, Portugal

b USDA Forest Service, Pacific Southwest Research Station, 1700 Bayview Drive, Arcata, CA 95521, USA

Keywords: Salvage Logging, Soil Compaction, Skid Trail, Post-fire, Management

\section{Acknowledgements}

This research was carried out in the framework of the research contract (CDL-CTTRI-88-ARH/2018 REF.138-88-ARH/2018) of the first author, funded by national funds (OE), through the Portuguese Foundation for Science and Technology (FCT/MCTES), in the scope of the framework contract foreseen in the numbers 
4, 5 and 6 of the article 23, of the Decree-Law 57/2016, of August 29, changed by Law 57/2017, of July 19. Thanks are also due for the financial support to CESAM (UID/AMB/50017/2019), to FCT/MCTES through national funds, and the cofounding by the FEDER, within the PT2020 Partnership Agreement and Compete 2020. USDA Forest Service, Pacific Southwest Research Station provided some additional funds for supplies and travel. We thank Jayme Seehafer and Susan Edinger Marshall for their assistance in our lab analysis, Diane Sutherland, Will Olsen, Drew Coe, Sergio Prats Fons and Pilar Alegre Espada for their help with the field work. We also thank Will Olsen for an early version of Fig. 1, and Pete Robichaud and Bob Brown for the use of the simulator and associated supplies. We also thank CALFIRE and the BMDSF staff for their cooperation at the field location.

\section{Data Availability}

The data that support the findings of this study are available from the corresponding author Dr. S.A. Prats upon reasonable request.

\section{Hosted file}

2.Manuscript01.docx available at https://authorea.com/users/331596/articles/458213compaction-and-cover-effects-on-runoff-and-erosion-in-post-fire-salvage-logged-areasin-the-valley-wildfire-california

\section{Hosted file}

3.Tables\&Figurecaptions01.docx available at https://authorea.com/users/331596/articles/ 458213-compaction-and-cover-effects-on-runoff-and-erosion-in-post-fire-salvage-loggedareas-in-the-valley-wildfire-california 


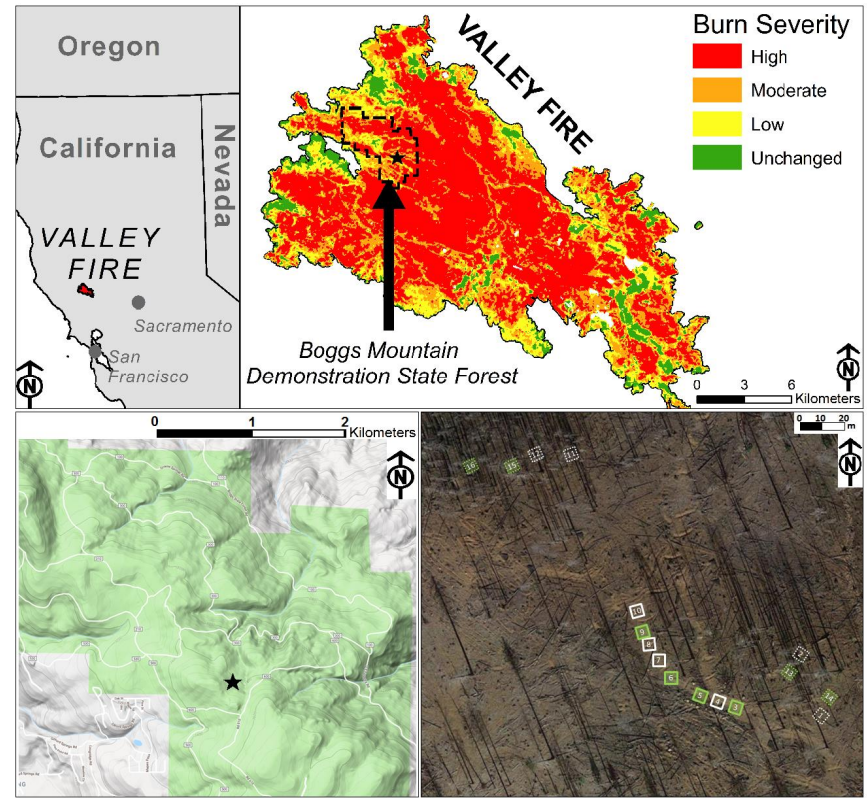

Figure 1. Top: Location of the 2015 Valley Fire and Boggs Mountain Demonstration Site Forest (BMDSF) in California. Bottom: Study site for the 16 rainfall simulations within the BMDSF (green shading). White and green-shaded squares in lower right panel correspond to bare and slash-covered plots, respectively, and dashed or bold lines correspond to uncompacted and compacted plots, respectively. Top panel from Olsen, 2016. 


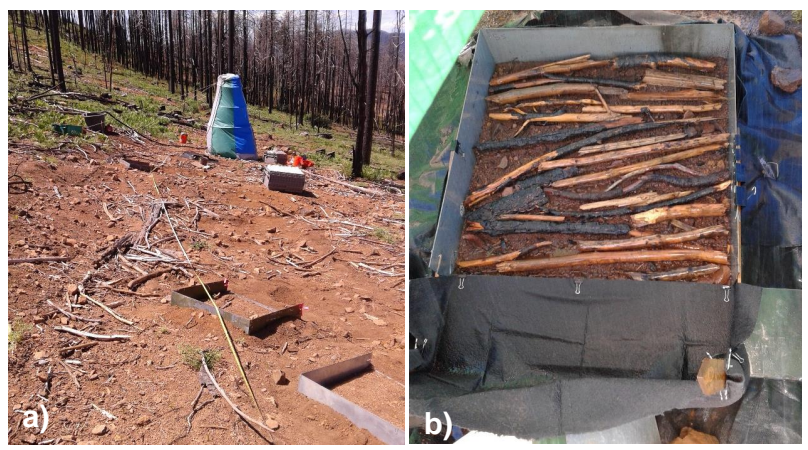

Figure 2. Portable rainfall simulator assembled over one plot on the skid trail, with windshelter in place (a) and detail of a compacted and slash-covered plot and the splash collecting system (b). 


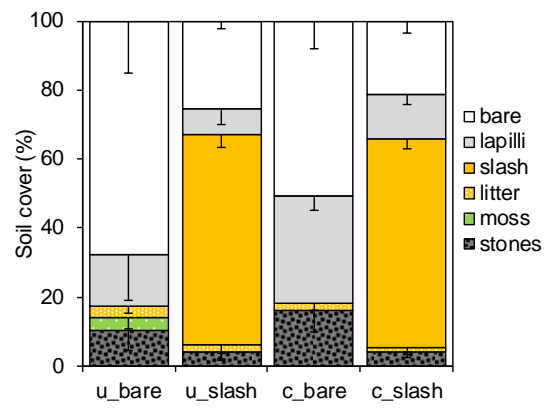

Figure 3. Mean soil cover for the four treatments. Cover categories included: added slash, litter (mainly leaves and small roots), mosses and two stone categories: lapilli (small

spherical stones $<5 \mathrm{~mm}$ diameter) and stones $(>5 \mathrm{~mm}$ ). Vegetation was trimmed from the plots before measurements occurred. Downward error bars (one standard deviation) were removed for clarity. Abbreviations are: u, uncompacted; c, compacted; bare, bare soil; and slash, $60 \%$ slash cover added. 

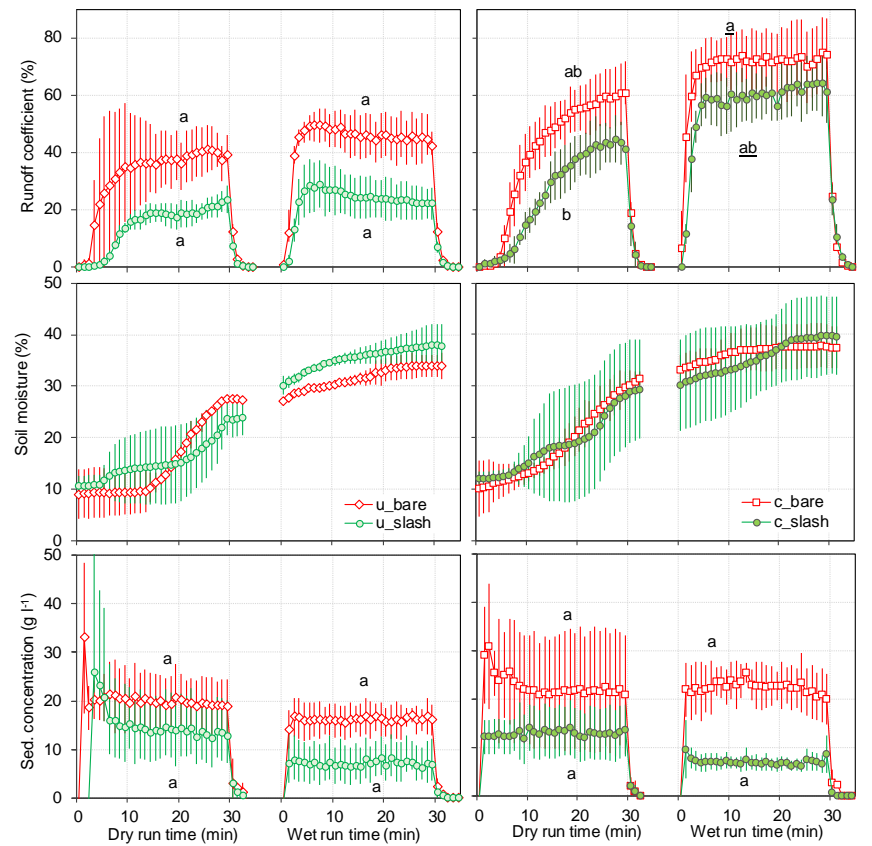

Figure 4. Mean runoff coefficient (\% of rainfall rate), soil moisture at $3 \mathrm{~cm}$ depth (\% volume) and sediment concentration $\left(\mathrm{g} \mathrm{l}^{-1}\right)$ for the four treatments at 1-minute intervals for the Dry and Wet runs. Treatments within the same run were statistically different when followed by different letters. Differences between runs for a given treatment were significant when letters are highlighted differently (plain text vs. underlined). Treatment abbreviations are: $u_{-}$: uncompacted, c_: compacted, bare: bare soil, slash: slash. 


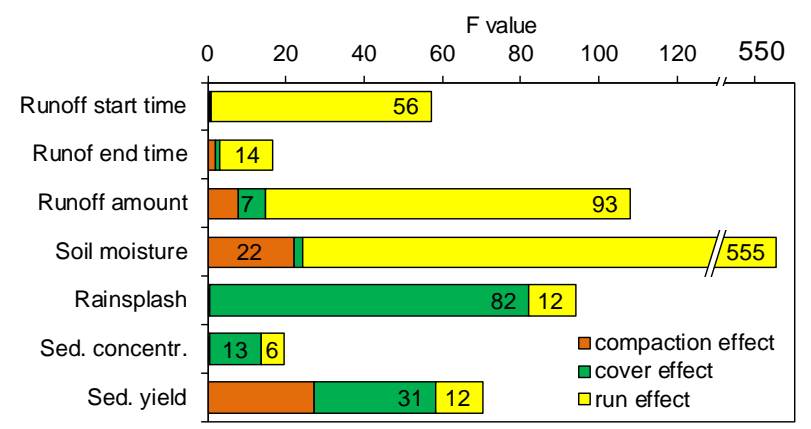

Figure 5. F values for the three-way mixed-effects statistical models comparing the impact of compaction (uncompacted/compacted), cover (bare/slash) and rainfall run (dry/wet) on dependent variables of runoff start and end times $(\mathrm{s})$, runoff amount $(\mathrm{mm})$, soil moisture $(\%$ volume), rainsplash (g), sediment concentration ("Sed. concentr."; $\mathrm{g} \mathrm{l}^{-1}$ ) and sediment yield ("Sed. yield"; $\mathrm{g} \mathrm{m}^{-2}$ ). Runoff start and end times and rainsplash were fourth-root transformed prior to analysis. F values are shown for the corresponding factor when they were significant at $p \leq 0.05$ 


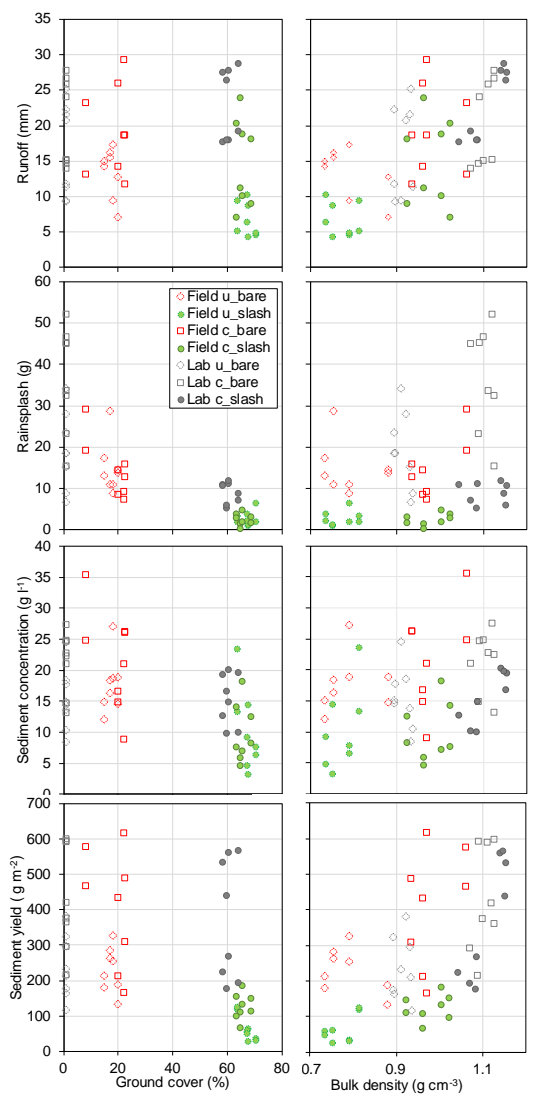

Figure 6. Runoff $(\mathrm{mm})$, rainsplash $(\mathrm{g})$, sediment concentration $\left(\mathrm{g} \mathrm{l}^{-1}\right)$ and sediment yield $\left(\mathrm{g} \mathrm{m}^{-}\right.$ $\left.{ }^{2}\right)$ versus soil ground cover (left panels) and bulk density (right panels) for the Dry and Wet runs from the field (colored symbols) (this study) and laboratory rainfall simulations (grey symbols) of Prats et al. (2019a). Note that symbols are empty for bare, filled for $60 \%$ slash cover, light line weight for uncompacted and heavy line weight for compacted. Abbreviations: u_: uncompacted, c_: compacted, bare: bare soil, slash: pine slash.

\section{Hosted file}

Table1.docx available at https://authorea.com/users/331596/articles/458213-compaction-andcover-effects-on-runoff-and-erosion-in-post-fire-salvage-logged-areas-in-the-valleywildfire-california

\section{Hosted file}

Table2.docx available at https://authorea.com/users/331596/articles/458213-compaction-andcover-effects-on-runoff-and-erosion-in-post-fire-salvage-logged-areas-in-the-valleywildfire-california

\section{Hosted file}


Table3.docx available at https://authorea.com/users/331596/articles/458213-compaction-andcover-effects-on-runoff-and-erosion-in-post-fire-salvage-logged-areas-in-the-valleywildfire-california

\section{Hosted file}

Table4.docx available at https://authorea.com/users/331596/articles/458213-compaction-andcover-effects-on-runoff-and-erosion-in-post-fire-salvage-logged-areas-in-the-valleywildfire-california 